\title{
Seroprevalence of Human T-Lymphotropic Virus Type I (HTLV-I) in Costa Rica
}

\author{
RIMA F. KHABBAZ, ${ }^{1}$ TRUDIE M. HARTLEY, ${ }^{1}$ MARK W. OBERLE, ${ }^{1}$ \\ and LUIS ROSERO-BLXBY ${ }^{2}$
}

I NFECTION WTRH THE HUMAN T LYMPHOTROPIC vinus type I (HTLV-I), a yirus associated with two diseases, adult T-cell leukemia lymphoma ${ }^{1}$ and tropical spastic paraparesis/HTLV-I associated myelopathy, ${ }^{2}$ is prevalent in Panama ${ }^{3}$ and Colombia. To determine if HTLV-I is present in neighboring Costa Rica, we tested 436 sera from women who participated, tetween 1984 and 1985, in a case-sentrol study of cervical cancer in Costa Rica. ${ }^{5}$ These sera were all that were still available to us from the 765 collected from control participants in the study. Study participants had all been interviewed and tested for several serologic markers of sexually transminted diseases (STDs).

Tested women were similar to nontested control participants for age (range 25-59 years), ethnic group (predominantly caucasians and hispanics), sexual histories (measured by age at first sexual activity and lifetime number of sex partners), herpes simplex type 2 (HSV2) seroprevalence, and histories of STDs. All 436 sera were screened by a commercial HTLV-I enzyme-linked immunosorbent assay (ELISA) (Dupont Co., Wilmington, DE); all repeatably reactive sera were further tested by Western blot; sera with suspected HILV-I reactivity on Westem blot but not fulfiling the criteria for HTLV-I seropositivity (reactivity to p24 and an env gene product) ${ }^{6}$ were further tested by radioimmunoprecipitation assay. Seven sera (1.6\%) were repeatably reactive by ELISA; $3(0.68 \%)$ were positive for HTLV-I antibodies (to both p24 and gp46/or gp68); of the remaining ELISA reactive, 1 had reactivity to p 19 only on Westem blotting and 3 had no Western blot reactivity. The 3 HTLV-I-seropositive women were older (mean age 48) than HTLV-I seronegative women (mean age 40,p = NS median rwo-sample test); they tended to be less educated and none lived in the densely populated capital area. All 3 were caucasian and they lived in different parts of the country; all 3 had lived, as children, in the same county (Canton). While none gave a history of any STD, 2 were reactive for syphilis by microhernagglutination assay for antibody to Treponema pallidum (MHATP), compared with 3 I of 432 (7.2\%) HTLV-I-seronegative women; all 3 were positive for HSV-2 antibodies, as were 196 of 426 (46\%) HTLV-I-seronegative women; and all 3 were seropositive for Chlamydia (titer $\geqslant 16$ ), as were $56.1 \%$ of HTLV-I-seronegative women.

To our knowledge, this report is the first to document HTLV-I seroprevalence in Costa Rica. A female predominance of HTLV-I seropositivity has been noted in virtually all endemic areas: by testing only women. we therefore most likely obtained a maximal estimate of the seroprevalence of HTLV-I in Costa Rica. which appears to be less than $1 \%$. Our $0.68 \%$ rate is much lower than the rates that have been reported for other - countries in the area including neighboring Panama. ${ }^{3}$ This difference in rates is due in part to the increased specificity of the HTLV-I serologic assays that we used;' in fact, our rate for Costa Rica is similar to current estimates for Panama (W. Reeves, personal communicasion); the difference in rates may also be related to other differences between the populations of these countries. Our numbers are too small to allow any evaluation of risks; however, the relatively older age of the HTLV-I-seropositive women and the association with STD markers are consistent with a sexual mode of transmission.

'Centers for Disease Control, Allanta, Georgia.

"University of Costa Rica Instinte for Health Research (NISA). San Jose. Costa Rica. 


\section{KHABBAZ ET AL.}

\section{REFERENCES}

1. Kuefler PR and Bunn PA jr. Adult T cell leukaemiajlymphoma. Clin Haematol 1986;15:695-726.

2. Osame M, Matsumoto M, Usuku K, tzumo S, Ijichi N, Amitani H, Tara M, and Igata A: Chronic progressive myeiopathy associated with elevated antibodies to human $T$-lymphotropic virus type $I$ and adult T-cell leukemialike cells. Ann Neurol 1987;21:117-122.

3. Reeves WC, Saxinger C, Brenes MM, Quiroz E, Clark JW, Hoh MW, and Blattner WA: Human T-ceil lymphotropic virus type I (HTLV-I) seroepidemiology and risk factors in metropolitan Panama. Am J Epidemiol 1988; 127:532-539.

4. Blattner WA and Gallo RC: Human T-cell lymphotropic virus: Comparative epidemiology. In: Proceedings of the XIlth Symposium of the International Association for Comparative Reseanch on Leukemia and Related Diseases. F. Deinhardt (ed.). Hamburg, 1986; pp. 361-382.

5. Oberle MW, Rosero-Bixby L, Irwin KL. Fortney JA. Lee NC. Whatley AS, and Bonhomme MG: Cervical cancer risk and use of depot-medroxyprogesterone acetate in Costa Rica. Int J Epidemiol 1988;17:718-723.

6. Centers for Disease Control: Licensure of screening tests for antibody to human I-lymphotropic vinis type I. Morbid Mortal Weekiy Rep 1988;37:736-747.

7. Weber JN, Banatvala N, Clayden S. McAdam J. Palmer S, Moulsdal H. Torswill J, Dilger P. Thorpe R. and Amann S: HTLV-I infection in Papua New Guinea: Evidence for serologic false positivity. J Infect Dis 1989:159:1025-1028.

8. Murphy E, Figueroa JP, Gibbs WN, Brathwaite A, Holding-Cobham M, Waters D, Cranston B, Hanchard B, and Blàtmer WA: Sexual transmission of human T-lymphotropic virus type I (HTLV-I). Ann Intern Med -1989:1 14:555-560.

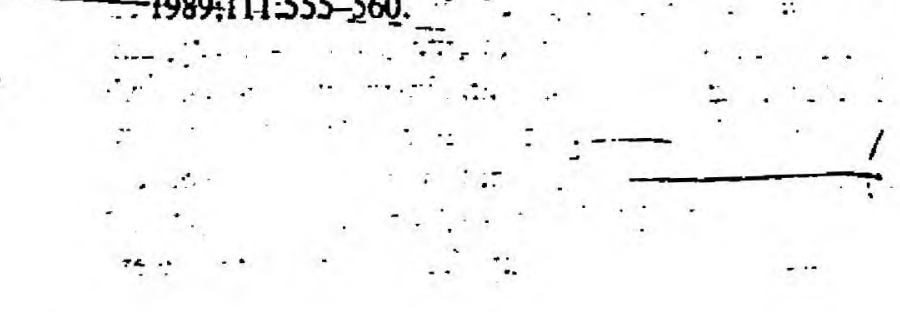

Address reprint requests to:

Rima F. Khabbar, M.D.

6-123-A 32

Retrovirus Diseases Branch

Center for Infectious Diseases 1600 Clifton Road

Atlanta, GA 30333 